\title{
Przykłady kooperatyw spożywczych w Polsce jako laboratorium inicjatyw społecznościowych
}

\section{KEYWORDS}

community initiatives, community institutions, public pedagogy, constructing the common good

\begin{abstract}
Bohdan Skrzypczak, Przykłady kooperatyw spożywczych w Polsce jako laboratorium inicjatyw społecznościowych [Examples of food cooperatives in Poland as a laboratory of social initiatives]. Kultura - Społeczeństwo - Edukacja nr 2(18) 2020, Poznań 2020, pp. 55-67, Adam Mickiewicz University Press. ISSN 2300-0422. DOI 10.14746/ kse.2020.18.3.1.
\end{abstract}

The paper discusses new forms of social collaboration that have been actively developing in cities for a number of years now. The text analyses the form of social interactions that the author has defined as a community institution. Applying this cognitive category to a reflection on a specific example - a food cooperative - made it possible to capture the characteristic features of a community self-organisation mechanism. Discovering the institutional aspects of the discussed phenomenon made it possible to observe that community collaboration involves an educational process of constructing the common good and consequently - a major potential of pedagogical impact and significant impact on local public policies.

Przynajmniej od kilku lat intensywnie rozwija się pedagogiczna refleksja wokół kategorii współbycia. Stopniowo tworzy się subparadygmat określany jako pedagogika współbycia, który stara się określić i zdefiniować pojęcia współzawodnictwa, współpracy, współdziałania przede wszystkim w obszarze praktyki oświatowej (Dymara, 2014: 35). Równolegle obserwujemy erupcję różnorodnych innowa-

* ORCID: 0000-0001-6982-8621. 
cyjnych form współdziałania obywatelskiego i społecznego w przestrzeni i sferze publicznej ${ }^{1}$. Edukacyjne aspekty tej aktywności stanowią pole badawcze rozwijanej od kilku lat przez autora artykułu koncepcji pedagogiki publicznej rozumianej jako subparadygmat/perspektywa pedagogiki społecznej (Skrzypczak, 2016a). Część tych zjawisk nowego typu społecznego współbycia określa się terminem inicjatywy społecznościowe ${ }^{2}$ (Skrzypczak, 2016b). W przedkładanym artykule na przykładzie kooperatyw spożywczych - przybliżony zostanie społecznościowy mechanizm samoorganizacji i instytucjonalizacji, którego rezultatem jest wychowawczy proces wytwarzania wspólnego dobra.

\section{Miasto - laboratorium inicjatyw społecznościowych}

Komentując zjawisko nowych inicjatyw społecznościowych, często akcentuje się jego spontaniczność, mało sformalizowany charakter działań oraz autonomiczny sposób myślenia o partycypacji społeczno-obywatelskiej. Tego typu współpraca pozwala bowiem, by każdy człowiek, nawet niemający siły i indywidualnego znaczenia, mógł zmienić reguły gry i uzyskać wraz z innym wpływ na otaczającą go rzeczywistość. Nowy, społecznościowy wymiar inicjatyw obywatelskich ma swoje źródła w przemianach więzi społecznej, jakie zaszły pod koniec XX wieku, a których najbardziej widoczną cechą jest narastająca indywidualizacja. Od jednostek wymaga ona prowadzenia niezależnego życia, kształtowania swojej tożsamości i biografii oraz samodzielnego podejmowania decyzji dotyczących norm i wartości (Beck, Giddens, Lash, 2009: 29). Z kolei sam termin „społecznościowy” jest w dużej mierze wynikiem ekspansji technologii internetowej, w której nowego znaczenia nabrało pojęcie społeczności. Dzięki temu, że przez Internet i telefony komórkowe komunikacja stała się łatwiejsza, a związku z tym wzrosła częstotliwość kontaktów z innymi osobami, wykształcają się różnorodne społeczności zapewniające jednostce wsparcie, towarzystwo, informacje czy poczucie społecznej łączności. Na tym społecznym doświadczeniu tworzy się nowa „architektura uczestnictwa” polegająca na wykorzystaniu potencjału użytkownika, czyli aktywizacji grup i zbiorowości do działań opartych na wzajemnej pomocy, komunikacji i współpracy. Za

\footnotetext{
1 Temu zagadnieniu poświęcone było zorganizowane na Wydziale Studiów Edukacyjnych UAM Ogólnopolskie Forum Dyskusyjne Pedagogów Społecznych pt. Pedagogika współbycia inspiracja do działania w przestrzeni życia lokalnego, w ramach którego powstał ten artykuł.

2 Przykładami są między innymi: banki czasu, ogrody społecznościowe, kooperatywy, kawiarenki naprawcze, centra społecznościowe / sąsiedzkie, grupy rolnicze wspierane przez społeczność, inicjatywy foodsharingowe.
} 
pomocą interaktywnej komunikacji sieciowej zwykli ludzie mogą robić teraz to, co niegdyś było w zasięgu jedynie dużych, scentralizowanych organizacji. Wynikiem tego typu zjawisk jest wyodrębnienie w przestrzeni obywatelskiej aktywności tzw. sektora społecznościowego (community sector) różniącego się od sektora pozarządowego (Chimiak, Iwińska, 2014; Krenz, Mocek, Skrzypczak, 2015). Z kolei w obszarze gospodarczym obserwujemy kształtowanie się i ekspansję tzw. ekonomii współdzielenia (sharing economy). Oba nurty łączy społecznościowy mechanizm współdziałania. Szczególnie inspirującym przykładem ilustrującym tego typu zjawiska mogą być kooperatywy spożywcze, które działają na styku aktywności społecznej, obywatelskiej i gospodarczej. Poza tym - wykorzystując współczesną komunikację sieciową i media społecznościowe - silnie odwołują się do tradycji, czyli idei i ruchu kooperatyzmu z przełomu XIX i XX wieku.

Przestrzenią, w której intensywnie powstają i rozwijają się kooperatywy i inne inicjatywy społecznościowe, jest dzisiaj miasto. Fundamentem istnienia miasta jest bowiem jednoczesne współdziałanie wielu zbiorowości ludzi. Co ważne, służy ono nie tylko realizacji potrzeb życiowych mieszkańców i przyjezdnych, ale kreuje także znaczenia symboliczne. Miejskość zawiera w sobie charakterystyczny paradoks. $\mathrm{Z}$ jednej strony związana jest $\mathrm{z}$ wyobcowaniem, $\mathrm{z}$ drugiej jest przestrzenią dużego nasycenia kontaktami międzyludzkimi wynikającymi ze znacznego zagęszczenia mieszkańców na określonym terytorium (Kłosińska, 2010). Miasto narzuca życie „W tłoku”, ale jednocześnie daje człowiekowi większą wolność, możliwość wyboru, przemieszczania się, której nie ma w małej społeczności wiejskiej. Jak zauważa Zygmunt Bauman w Razem czy osobno (2013: 15): „Fizyczna bliskość obcych jest [...] losem mieszkańców miast, dlatego muszą eksperymentować, wypróbowywać i sprawdzać różne sposoby życia, wierząc, że znajdą wreszcie taki modus vivendi, który uczyni ich współżycie z obcymi możliwe do przyjęcia”. Dlatego to w miastach kształtowały się i kształtują nowatorskie strategie tworzenia więzi grupowych i sposobów zarządzania wspólnotą. „Miasta są dziś laboratoriami przyszłości, w których są odkrywane i wynajdywane nowe formy życia społecznego oraz wytwarzania tego, co wspólne" (Bendyk, Hausner, Kudłacz, 2015: 122).

Eksperymentowanie staje się częścią polityki miejskiej. Przejawem zorganizowanego podejścia do stymulowania innowacyjności miejskiej są powstające w wielu miastach europejskich i polskich tzw. laboratoria innowacji (innovation lab). Są to jednostki organizacyjne (prowadzone przez samorząd lub na zlecenie miasta przez organizacje pozarządowe), których celem jest projektowanie, testowanie i skalowanie innowacji społecznych w ramach międzysektorowej współpracy. Jak pisze Elżbieta Bińczyk (2013: 64), „laboratorium jest specyficzną przestrzenią, gdzie intencjonalnie tworzy się możliwie układy / pomysły społeczne, ale nie chodzi o pracę nad teo- 
retycznymi konceptami, lecz o sukces praktyczny polegający na uzyskaniu sukcesu w działaniu w konkretnej społeczności, a także na pewnego rodzaju powtarzalności wyników". W tym nurcie umieścić możemy też Warszawskie Laboratorium Innowacji Lokalnych, które działało w latach 2016-2018 w ramach programu „Warszawa Lokalnie"3. Aktywność tego laboratorium skoncentrowana była na poszukiwaniu mechanizmów wytwarzania społecznościowych więzi i współpracy mieszkańców Warszawy. Badania i debaty środowiskowe prowadzono w nurcie określanym przez autora jako pedagogika publiczna (public pedagogy), dotyczyły one pedagogicznych kontekstów oddziaływania oddolnych inicjatyw samoorganizacyjnych mieszkańców oraz edukacyjnych form ich wspierania (lub nie) w ramach miejskich polityk publicznych. Wśród 16 studiów przypadku inicjatyw społecznościowych opracowanych w ramach laboratorium znalazło się studium dotyczące kooperatyw spożywczych, które stosunkowo najpełniej ukazuje edukacyjne oraz społecznościowe mechanizmy współpracy i współbycia w przestrzeni miejskiej (Skrzypczak, Urbańska, 2016). Badanie, którego wybrane elementy przedstawia prezentowany tekst, przybliża mechanizm współdziałania kooperatyw z trzech perspektyw poznawczych: 1) samoorganizującej się i multifunkcjonalnej społeczności, 2) tworzenia nowego typu instytucji o charakterze społecznościowym oraz 3) uruchamiania wychowawczego procesu budowania dobra wspólnego.

\section{Multifunkcjonalna społeczność konsumpcyjna i edukacyjna}

Kooperatywa jest nieformalną spółdzielnią spożywczą, inicjatywą świadomych konsumentów, tworzy społeczność, która chce pozyskiwać zdrową żywność w sprawiedliwych cenach. Budujemy sieć współpracy producentów i konsumentów, w której celem jest zaspokajanie potrzeb stron, a nie zysk. Kooperatywa zrzesza osoby, którym zależy na wcielaniu w życie idei spółdzielczości. Pozwala nam to nabywać produkty znacznie taniej, zazwyczaj bezpośrednio od producentów deklarują warszawscy spółdzielcy na stronie internetowej (Bilewicz, 2015: 1). Kooperatywa spożywcza to jednak nie tylko cotygodniowe zakupy zdrowej żywności. Osoby zaangażowane w tę działalność wskazują także na cele społeczne i edukacyjne. Kooperatywa umożliwia swoim członkom nawiązywanie nowych kontaktów towarzyskich, wymianę poglądów oraz realizowanie nowych wspólnych inicjatyw skierowanych do społeczności lokalnej. „Tu nie chodzi o to, żeby to była sprawna,

\footnotetext{
${ }^{3}$ Prowadzone było przez stowarzyszenie Centrum Wspierania Aktywności Lokalnej CAL w Warszawie ze środków samorządu warszawskiego. Pracami badawczymi kierował autor artykułu Bohdan Skrzypczak.
} 
anonimowa organizacja, gdzie dostępne są tanie i ekologiczne warzywa. Kooperatywa toludzie, którzy się znają, lubią się i chcą coś razem zrobić” (Podkańska, 2013: 56). Dla niektórych członków ten społeczny wymiar jest nawet bardziej istotny niż aspekt konsumencki. Kooperatywy stawiają przed sobą dwa cele:

- sprzedawać po niższych cenach żywność kupowaną bezpośrednio od producentów;

- tworzyć demokratyczną wspólnotę pomocy wzajemnej (np. poprzez fundusz gromadzki zbierany w postaci 10\% kwoty od każdych zakupów na cele wspólne spółdzielni oraz wsparcie członków w potrzebie).

W Warszawie funkcjonuje ok. 10 grup, które określają się mianem kooperatyw. Są to w większości grupy nieformalne, które ulegają szybkim przemianom: jedne zawieszają swoją aktywność, inne powstają, nowi członkowie przychodzą i odchodzą, a niektóre kooperatywy przekształcają się w formalne organizacje. Można oszacować, że średnio jedna kooperatywa liczy ok. 50 osób, choć do niektórych okresowo należało ponad $500^{4}$. Niezależnie od tych podziałów łączą je wspólne cechy, spośród których w tym miejscu podkreślone zostaną te, które składają się na jej wymiar wspólnotowy / społecznościowy.

Uczestnicy kooperatyw cenią sobie przede wszystkim wymiar wspólnotowy i towarzyski. W ich ramach organizowane są spotkania, warsztaty, wspólne posiłki, otwarte pikniki w miejskich parkach, dyskusje czy pokazy filmów. Respondenci w badaniach wskazują na przykład: „Oczywiście jedzenie jest istotne, ale jest w tym coś więcej, nie chodzi tylko o jedzenie, bo mogę pójść na targ i sobie to jedzenie kupić, i może nawet byłoby to szybciej, natomiast ważne jest to, że tworzy się grupa. I to, że jest to pewna społeczność" (Podkańska, 2013: 57). Inny rozmówca określał kooperatywę w ten sposób: „To takie małe społeczeństwo, bo to właściwie jest społeczność. Wprowadzenie jednolitych zasad skodyfikowanych w regulaminie i ograniczenie liczby członków Kooperatywy sprawiło, że odrodziła się pierwotna idea wspólnoty i kooperacji. [...] Po kilku miesiącach od wdrożenia zmian Kooperatywa Grochowska osiągnęła optymalną wielkość około stu członków, zapewniającą równowagę pomiędzy siłą przetargową i nabywczą a możliwością utrzymania kontaktu i więzi z pozostałymi członkami” (Skrzypczak, Urbańska, 2016: 45).

Społeczność kooperatyw łączy i angażuje się w pełnienie wielu funkcji. Po pierwsze, kooperatywa jest instrumentem do realizowania potrzeb konsumenckich. Dla wielu członków ważna jest także funkcja edukacyjna tej inicjatywy. Zaangażowanie w działalność kooperatywy pozwala na rozwijanie umiejętności

\footnotetext{
${ }^{4}$ Dla porównania - pod koniec lat 30. XX wieku największy związek spółdzielczy w Polsce, „Społem”, liczył ok. 600 tys. członków.
} 
pracy w grupie, uczy podejmowania wspólnych decyzji i rozwiązywania sytuacji konfliktowych. Czyni to kooperatywę spożywczą swoistą szkołą kompetencji społecznych. Po trzecie, jest poligonem tworzenia więzi społecznych, sąsiedzkich, a także miejscem kształtowania tożsamości społecznej. Współcześnie, czy tego chcemy, czy nie, to w dużej mierze konsumpcja określa naszą tożsamość. Dlatego dla członków kooperatywy konkretne wybory konsumenckie, czyli zakupy żywności sezonowej i ekologicznej, ale niezbyt drogiej, są ważnym elementem projektowania własnej tożsamości. „Dla mnie członkostwo w kooperatywie i to, co konkretnie kupujemy, jest narzędziem do określenia samej siebie" (Podkańska, 2013: 54). Po czwarte, kooperatywy stymulują innowacyjność. Dzięki zaangażowaniu i kreatywności członków kooperatyw wokół ich działań powstaje wiele nowych inicjatyw niezwiązanych bezpośrednio z samymi zakupami. Są to: projekty ogrodnictwa miejskiego, grupa dyskusyjna podejmująca temat postwzrostu, społecznościowy system wymiany dóbr i usług, Grupa Rolnictwa Wspieranego przez Społeczność (ang. Community Supported Agriculture).

W niemal wszystkich kooperatywach mniejszym lub większym problemem jest niedostateczne zaangażowanie członków. Większość pracy często spoczywa na barkach kilku najbardziej zaangażowanych aktywistów. Część z nich wypala się i opuszcza kooperatywy. „Był duży problem związany z partycypacją i tym, że wziąłem na siebie za dużo obowiązków i nie było wystarczająco dużo rąk do pracy. I w pewnym momencie przegrzałem się, nie byłem w stanie wszystkiego ciągnąć i to skończyło się miesięcznym zawieszeniem działalności” (Bilewicz, 2015: 4).

Chaotyczność działania kooperatyw jest problemem szczególnie dla tych, którzy wstępują do nich głównie ze względu na dostęp do dobrej jakości i/lub tańszej żywności. Osoby, dla których kooperatywa jest swego rodzaju „naturalnym środowiskiem”, przechodzą nad tymi problemami, z większą lub mniejszą łatwością, do porządku dziennego. Organizacja, która pełni funkcję grupy towarzyskiej, realizującej jej wartości samym istnieniem, nie musi działać do końca efektywnie i sprawnie - istotne jest samo jej funkcjonowanie jako miejsca spotkań towarzyskich i realizacji ważnych idei.

\section{Kooperatywa spożywcza jako instyłucja społecznościowa}

Interesujące wnioski poznawcze przynosi - zdaniem autora - zastosowanie do analizy kooperatyw spożywczych perspektywy poznawczej nowego instytucjonalizmu. Tworzymy instytucje, ponieważ pomagają nam zmniejszać koszty transakcji społecznych i przyczyniają się do redukcji niepewności, jaką powodują owe transakcje. 
Dzięki scedowaniu odpowiedzialności na poziom instytucjonalny jednostki ponoszą mniejsze koszty transakcyjne, niż gdyby zdecydowały się wejść w interakcję bez pomocy pośrednika. Zapewniają jednostce bezpieczeństwo, regularność i niski koszt interakcji. „Mogą także opracowywać i narzucać innym własne reguły. Osoby nawiązujące interakcje w konkretnej, określonej regułami sytuacji związanej z danym środowiskiem mogą z czasem przyjąć normy dotyczące zachowań wobec innych ludzi oraz ich działań. W miarę poznawania konsekwencji własnych i cudzych zachowań w danej sytuacji uczestnicy omawianych interakcji mogą modyfikować normy i strategie działania, co prowadzi do lepszych lub gorszych następstw dla nich oraz dla środowiska, którego te działania dotyczą" (Ostrom, 2012: 88).

Reguły wypracowane i stosowane w ramach instytucji pełnią funkcję scalającą, uruchamiają rutynowe działania, procedury, role, strategie, formy organizacyjne, obowiązującą kulturę grupy, społeczności. Przyjmując tę perspektywę poznawczą, niesformalizowane inicjatywy społecznościowe, które silnie krytykują instytucje w jej potocznym rozumieniu (czyli jako organizacje), tworzą nowy rodzaj instytucji określany właśnie jako społecznościowy. Są one formą pośredniczącą usytuowaną pomiędzy, z jednej strony, nastawianą na maksymalizację indywidualnych korzyści jednostką a interesem wspólnym, z drugiej strony, łączą przeszłość z teraźniejszością i przyszłością, redukując niepewność w życiu społecznym. W takiej interpretacji instytucje to nie tyle ludzie, co prawidłowości (zwyczaje i reguły) ujawniające się w powtarzalnych interakcjach człowieka (North, 1986: 231). Kooperatywy, a także inne inicjatywy społecznościowe są w większości organizacjami zarządzanymi w sposób niehierarchiczny, a takie funkcje, jak przywiezienie towaru, ważenie, zbieranie pieniędzy czy sprzątanie sprawowane są rotacyjnie. Niektóre z nich, starając się usprawnić działania, wprowadziły funkcje koordynatorów, których kadencja trwa kilka miesięcy. Oparte są na bezpośredniej współpracy z rolnikami. Przede wszystkim chodzi o niewielkie gospodarstwa często ukierunkowane na produkcję ekologiczną.

Kooperatywa stanowi przykład nieformalnej organizacji o płaskiej strukturze zarządzania, w której decyzje podejmowane są w drodze konsensusu. Sama organizacja zakupów przebiega rotacyjnie, członkowie są podzieleni na grupy, które są odpowiedzialne za organizacje kolejnych zakupów. Pełnienie funkcji zakupowych nie jest obowiązkowe, podobnie jak udział w zakupach, co powoduje narastający problem „pasażerów na gapę” (Podkańska, 2013: 56). Ważne jest ciągłe mobilizowanie członków do udziału w zakupach, ale i do czynnego zaangażowania przy ich organizacji. Jednym z głównych celów kooperatywy jest wypracowanie najlepszego modelu organizowania produkcji i dystrybucji żywności, dzięki któremu członkowie grupy zyskają dostęp do zdrowych i tanich produktów bezpośrednio od rolnika. Członkowie kooperatyw pragną odzyskać kontrolę nad wyborami 
konsumenckimi, dlatego dla wielu z nich kontakty z producentem żywności czy bezpośredni udział w procesie zakupów żywności na giełdzie stanowią większą wartość niż fakt oznakowania danych produktów certyfikatami ekologicznymi. Często podkreślają, że ich celem jest działalność poza rynkiem komercyjnym, ponieważ chcą działać na lokalnym rynku i wspierać lokalnych rolników. Deklarują, że ich celem nie jest przeprowadzenie rewolucji, ale wypracowanie alternatywnego modelu organizacji produkcji i dystrybucji żywności oraz przetestowanie go w małej skali (Skrzypczak, Urbańska, 2016: 28).

Kooperatywa jest także próbą odbudowy kultury współdziałania ludzi w przedsięwzięciach nastawionych nie na osiągnięcie zysku, ale na realizację wspólnych celów. Ważnym mechanizmem rozwoju instytucjonalnego kooperatyw jest ich współpraca z innymi instytucjami publicznymi lub pozarządowymi. „Korzystanie z przestrzeni w Centrum Społecznym Paca 40 (organizacja użyczająca bezpłatnie miejsca na odbiory), udostępnianie jej na cotygodniowe odbiory Kooperatywy daje możliwość zwiększenia skali działania. Dzięki temu kooperatywa zaczęła się niezwykle dynamicznie rozwijać. Wzrosła liczba dostawców, jedne odbiory często skupiają ponad dwudziestu dostawców, znacznie wzrósł wybór nabiału, drobiu i mięsa, zaplecze z dwiema podarowanymi przecz członków kooperatywy lodówkami daje dużo większe możliwości” (Skrzypczak, Urbańska, 2016: 38).

Kooperatywy spożywcze, mimo że dążą do pewnej przewidywalności i regularności transakcji społeczno-ekonomicznych, które zapewniać ma instytucja, jednocześnie uważają, że nadmierne unormowanie jest nieefektywne i niepożądane. Zjawisko to George Ritzer (1997) nazwał nieracjonalną racjonalnością, ponieważ polski system prawny nie przewiduje istnienia kooperatyw. Najbliżej im do definicji spółdzielni, ale i w tym pojęciu prawnym nie znajdują swojego miejsca. W związku z tym, że kooperatywy spożywcze nie mają w Polsce własnej osobowości prawnej, muszą sobie radzić, ustanawiając poprzez partycypacyjnie uchwalane regulaminy wewnętrzne jasno i precyzyjnie określone obowiązki ich członków, obligując wszystkich do zaangażowania i aktywności. Każdy musi nie rzadziej niż raz na dwa miesiące kupić coś w ramach jednej akcji i poświęcić się pracy na rzecz grupy przynajmniej przez trzy godziny miesięcznie. Regulaminowe godziny można odpracować też w inny sposób, na przykład sprzątając salę po odbiorach, pomagając nowym członkom w organizacji pierwszej akcji, rozliczając składki lub pozyskując nowych dostawców dla grupy czy też koordynując zamówienia. „Inną opcją jest wykonanie pracy na rzecz Centrum Paca 40 lub organizacja warsztatów, prelekcji czy wydarzeń integracyjnych. Czas rozliczany jest arbitralnie, ważne, by każdy poczuwał się do wspólnoty - wszystkie aktywności na rzecz kooperatywy wpisuje się do tabeli rozliczenia zaangażowania" (Skrzypczak, Urbańska, 2016: 37). 
Regulamin i wszystkie dokumenty dotyczące jej funkcjonowania dostępne są w sieci. Kooperatywa funkcjonuje w ramach grupy na portalu Facebook. W zamkniętej grupie pojawiają się szczegółowe informacje o zbliżających się wydarzeniach, dyskusje o bieżących sprawach i wszelkiego rodzaju ogłoszenia. Pod opisy wydarzeń podpięte są dostępne $\mathrm{w}$ chmurze tabele do składania zamówień opracowane według jednolitego schematu. „Proste, ogólnodostępne narzędzia i portal społecznościowy jako platforma funkcjonowania kooperatywy sprawdzają się wyśmienicie" (Skrzypczak, Urbańska, 2016: 41).

W przypadku kooperatyw mamy do czynienia z ciekawym złączeniem „człowieka ekonomicznego" (homo economicus) z „człowiekiem obywatelem” (homo politicus) - skłonnym do kooperacji i renegocjowania zasad gier społecznych, zainteresowanym pielęgnowaniem więzi zbiorowych. Przy takim podejściu uwaga skupiona jest na współpracy jako bardziej korzystnej strategii, a nie na forsowaniu indywidualnej kalkulacji. Tego typu ekonomiczna kooperacja okazuje się swoistą szkołą demokracji, gdyż w praktyczny, angażujący wszystkich zainteresowanych sposób uczy oddolnej budowy ładu społecznego. Mamy więc do czynienia także z pedagogicznym rozumieniem instytucji uznającym, że nie istnieje ona jedynie $\mathrm{w}$ aspekcie realnym, ale może być również stanem wyobrażonym i symbolicznym. Wzajemne powiązanie i napięcie w przestrzeni społecznej pomiędzy tym, co realne (nie jesteśmy z tego zadowoleni, krytykujemy obecne instytucje), a tym, co wyobrażone i symboliczne (jak chcemy, żeby było), może być istotnym elementem uruchamiającym dążenie do zmiany.

W badanych przykładach ujawnia się dwuwymiarowe postrzeganie instytucji. Po pierwsze, jest to reguła (wzór), a po drugie, podmiot, który może się odnosić do innych podmiotów (typ organizacji). Ważne jest w tym podejściu poznawcze oddzielenie instytucji od organizacji, mimo że zarówno jedna, jak i druga forma porządkuje ludzkie działania (Granosik, 2013: 67). W przypadku kooperatyw bardzo wyraźnie widać dwie odrębne ścieżki praktyki społecznej: pierwsza związana z refleksją nad sensem „bycia razem” w tym przedsięwzięciu oraz druga usprawniająca strukturę w jej wymiarze organizacyjnym i ekonomicznym.

Ponadto podkreślmy, że instytucje zawierają w sobie silny mechanizm kolektywny, dzięki któremu działania zbiorowe ukazują je jako alternatywę dla aktywności egoistycznych jednostek. Instytucja społeczna (i społecznościowa) to coś więcej niż suma działań pojedynczych jednostek. Rozwijana na tym gruncie refleksja nad (re)konstrukcją instytucji obywatelskich wychodzi z założenia, że „świat [...] nie jest prywatnym światem konkretnej jednostki, lecz światem intersubiektywnym, wspólnym nam wszystkim, stanowiącym dla nas wysoce praktyczny, a nie teoretyczny obiekt zainteresowania. [...] stanowi zarówno scenę, jak i obiekt naszych 
działań i interakcji” (Schütz, 2008: 18). W tym obszarze kooperatywy stanowią ciekawą innowację, która łączy sprzeczne (przynamniej pozornie) podejścia: zawiera silny pierwiastek wspólnotowy przy jednoczesnej obecności ekskluzywności i silnie podkreślanego indywidualizmu.

Kooperatywy wytwarzają model zarządzania, który umożliwia współpracę między osobami widzącymi korzyści ze wspólnego działania, przyczyniając się do wygenerowania ekonomicznie efektywnego przedsiębiorstwa. Użytkownicy tzw. prosumenci, a więc osoby zarazem wytwarzające, jak i konsumujące - korzystają ze wspólnych zasobów, co oznacza, że ich użycie zależne jest od decyzji grupy - gdy jesteś jej członkiem, masz prawo do ich użytkowania. Wspólne używanie zasobów jest poważnym wyzwaniem ekonomicznym i społecznym. Ze wspólnej pracy oraz użytkowania narodzić się może dylemat zmuszający poszczególnych członków grupy do wyboru między własnym, krótkoterminowym interesem a długofalowymi korzyściami dla wspólnoty. Wspólnotowcy (ang. commoners) tworzą reguły instytucjonalne umożliwiające interakcje wewnątrz grupy oraz rozwiązanie wspomnianych dylematów. W efekcie rodzi się nowa instytucja kolektywnego działania - instytucja społecznościowa. Jej kształt i funkcjonowanie są znacząco odmienne od rynkowego oraz samorządowego czy państwowego modelu zarządzania. Kluczowymi mechanizmami spajającymi tę formę współpracy są zasada wzajemności oraz równość przy procesach decyzyjnych. Egzekwowanie zasady wzajemności wymaga włączenia ludzi w procesy decyzyjne oraz zarządzania dobrem wspólnym. Ten nowy układ instytucjonalny oferuje dostatecznie dużą użyteczność uczestnikom indywidualnym przy jednoczesnym zapobieganiu nadmiernemu zużyciu zasobu wspólnego. Analizując mechanizmy społecznościowe i instytucjonalne kooperatyw, można wyodrębnić pewne wspólne reguły, sposoby działania i komunikacji składające się na kulturę organizacyjną, która została przez autora określona jako instytucja społecznościowa.

Tabela 1. Cechy instytucji społecznościowej

\begin{tabular}{|c|c|}
\hline \multicolumn{1}{|c|}{ Reguły współpracy } & \multicolumn{1}{c|}{ Sposób działania } \\
\hline - oparcie się na zasadzie wzajemności i wymianie & - brak ograniczeń formalnych i brak biurokracji \\
wiedzy/doświadczenia pomiędzy członkami & w realizacji inicjatyw \\
- wzajemne motywowanie i wspieranie z elemen- & - swoboda działania, wolność decyzji, dążenie do \\
tami kontroli & działania obywatelskiego „w czystej formie” \\
- demokratyczna struktura organizacyjna & - innowacyjność rozumiana jako realizacja nowych \\
& pomysłów w skali mikro, które dotyczą zwykle \\
& wąskiego wycinka rzeczywistości (zbiorowości) \\
& - ukierunkowanie na działanie, a nie metodykę \\
& i teorię \\
\hline
\end{tabular}




\begin{tabular}{|c|c|}
\hline Kultura działania & Zasady i formy komunikacji \\
\hline - aktywność społeczno-obywatelska rozumiana & - intensywna komunikacja i kontakty zapośred- \\
jako wymiar tożsamości i stylu życia & niczone przez media elektroniczne (media spo- \\
- inicjatywy społeczne wynikają z autonomicz- & lecznościowe) \\
nych (spontanicznych lub strategicznych) de- & - sieciowy charakter współpracy i relacji \\
cyzji aktywnych członków, których działania są & - komunikacja niehierarchiczna \\
$\begin{array}{l}\text { zorientowane na zmianę „tu i teraz” } \\
\text { opór i krytyka dominującego sposobu życia } \\
\text { oraz sektora pozarządowego }\end{array}$ & \\
\hline
\end{tabular}

Źródło: opracowanie własne.

\section{Konstruowanie instyłucji dobra wspólnego jako wyzwanie wychowawcze}

We współczesnych rozważaniach pedagogicznych o sprawach publicznych często przywoływane jest dobro wspólne, które oznacza, „po pierwsze, wyzwalający i oparty na współpracy porządek społeczny czy też konstrukcję instytucji pomyślanych specjalnie w tym celu, by wyzwalać wolne osoby; po drugie, konkretne osiągnięcie społeczne; po trzecie, punkt odniesienia” (Novak, 1998: 125). Chodzi o porządek społeczny, który ma być dopasowany do wolnych osób, a więc nie może być wyznaczony przez rządzących. W dominującym dotychczas w Europie publicznym dyskursie najczęściej wskazywano, że to rynek jest najlepszym społecznym urządzeniem służącym do realizacji wspólnych spraw. Zakładano, że jego słabe strony można niwelować odpowiednimi instytucjami publicznymi. Te jednak szybko przekształcają się w biurokratyczne struktury, które w żaden sposób nie mogą spełnić wspólnotowych nadziei. Wobec braku rozwiązań w głównym nurcie polityki publicznej pojawiły się idee alternatywne.

Instytucje społecznościowe, takie jak opisywana w tym tekście kooperatywa spożywcza, dają nadzieję, że mogą realizować większość wymogów związanych z wytwarzaniem wspólnego dobra. Po pierwsze, łączą aspekty ekonomiczne i społeczne oraz zbiorowe i indywidualne. Po drugie, pojawiają się tam, gdzie jakaś społeczność decyduje się zarządzać kolektywnie pewnym zasobem, uwzględniając przy tym równocześnie dostęp do niego i pożytków z niego płynących oraz zasadę utrzymania równowagi ekologicznej. Po trzecie, nawiązując do tradycji, wykorzystują najnowsze technologie komunikacyjne. Nowej, społecznościowej wykładni dobra wspólnego i nowemu rozumieniu współpracy towarzyszy uruchomienie ruchu społecznego, który za Ivanem Illichem można nazwać wernakularnym (1981). Tego typu aktywność - ruch - odwołuje się do nieformalnych przestrzeni kulturowych, w których ludzie dokonują niezawi- 
słych wyborów moralnych i mają wyraźnie zaznaczoną autonomię. Chodzi więc o przestrzeń współdzieloną przez społeczność, w której wspólne wartości i cele przeważają nad interesem państwa i korporacji. Nie ma dobra wspólnego bez „uwspólnienia” pisze Peter Linebaugh (2008), czyli decyzji danej społeczności. Droga do takiego rozumienia dóbr wspólnych wymaga myślenia w kategoriach praktycznych i polega na dostrzeganiu twórczego potencjału relacji społecznych i zrezygnowania z poszukiwań abstrakcyjnych, uniwersalnych lub proceduralno-prawnych. Liczy się relacja „tu i teraz”, a nie abstrakcyjne planowanie wspólnego dobra kiedyś w przyszłości. Na sposób społecznościowy pojmowane dobro wspólne działa wówczas, gdy ludzie się uczą i doświadczają zarządzania w konkretny i niepowtarzalny sposób wynikający z posiadanych zasobów. Istotna jest tu osobista i zbiorowa relacja między ludźmi a ich zasobami (Boiler, 2014: 15). Dobro wspólne jest przy takim podejściu autowychowawczą ideą realizowaną poprzez stosowanie praktyk społeczności uczącej się oraz wypracowywanie i wdrażanie zestawu działań społecznych, a więc wartości i norm niezbędnych do zarządzania zasobami. Tak rozumiany „mechanizm wychowawczy i społecznościowy” zawiera się w następującym wzorze: „społeczność + jej integrowanie / rozwijanie poprzez tworzenie sieci wewnętrznych i zewnętrznych relacji + jej instytucjonalizowanie poprzez negocjowanie / wprowadzanie zestawu procedur i wartości społecznych = daje w efekcie uruchomienie wewnętrznych i zewnętrznych zasobów". Dopiero takie zintegrowane zaistnienie wszystkich czynników wytwarza współzależne całościowe dobro wspólne (Boiler, 2014: 16). Wiele wskazuje na to, że kooperatywy spożywcze i inne inicjatywy / instytucje społecznościowe znalazły własną ścieżkę wprowadzania powyższego mechanizmu wychowawczego do praktyki społecznej, co z pewnością napawa nadzieją pedagogów społecznych od dawna poszukujących skutecznej pedagogii wspólnego dobra.

\section{Bibliografia}

Bauman Z. (2003), Razem czy osobno, Kraków.

Beck U., Giddens A., Lash S. (2009), Modernizacja refleksyjna. Polityka, tradycja i estetyka w porządku społecznym nowoczesności, Warszawa.

Bendyk E., Hausner J., Kudłacz M. (2016), Miasto-idea - nowe podejście do rozwoju miast, Kraków. Bilewicz A. (2015), Samoograniczająca się zmiana? Kooperatywy spożywcze w Polsce, „Nowy Obywatel”, http://nowyobywatel.pl/2015/05/06/samoograniczajaca-sie-zmiana-kooperatywy-spozywcze-w-polsce/ [dostęp: 20.04.2019].

Bińczyk E. (2013), (Post)konstruktywizm na temat technonauki, „Avant”, vol. 4, no. 1.

Bollier D. (2014), The Commons. Dobro wspólne dla każdego, Zielonka. 
Chimiak G., Iwińska K. (red.) (2014), Krajobraz społecznościowy, Warszawa.

Dymara B. (2014), Źródła, cechy i perspektywy pedagogiki współbycia, w: Dziecko w świecie innowacyjnej edukacji, współdziałania i wartości, t. 1, red. U. Szuścik, O. Oelszlaeger-Kosturek, Katowice.

Granosik M. (2013), Praca socjalna - analiza instytucjonalna z perspektywy konwersacyjnej, Łódź.

Illich I. (1981), Shadow Work, Boston.

Kłosińska M. (2010), Granice miejskości, „Antropos”, 14/15, file:///Users/Bohdan/Documents/ Moje\%20dokumenty/WARSZAWA/warszwskie\%20laboratorium/miejskość/miejskość.webarchive [dostęp: 15.04.2017].

Linebaugh P. (2008), The Magna Carta Manifesto: Liberties and Commons for All, Berkeley.

Mocek S., Skrzypczak B. (red.) (2015), Efekt motyla. Scenariusze rozwoju sektora społecznościowego w Polsce, Warszawa.

North D.C. (1986), The New Institutional Economics, „Journal of Institutional and Theoretical Economics", vol. 142.

Novak M. (1998), Wolne osoby i dobro wspólne, Kraków.

Ostrom E. (2012), Instytucje i środowisko, „Zarządzanie Publiczne”, nr 2 (20).

Potkańska D. (2014), Zmierzch epoki tradycyjnego konsumenta, czyli jak wspólne zakupy ekologicznej żywności kształtują tożsamość społeczną młodych Polaków. Odradzający się ruch żywieniowy kooperatyw spożywczych $w$ Polsce - przykład Warszawy, http://docplayer.pl/13473092-Dominika-potkanska-zmierzch-epoki-tradycyjnego-konsumenta-czyli-jak-wspolne-zakupy-ekologicznej-zywnosci-ksztaltuja-tozsamosc-spoleczna-mlodych.html [dostęp: 02.03.2018].

Ritzer G. (1997), Makdonaldyzacja społeczeństwa, Warszawa.

Schütz A. (2008), O wielości światów. Szkice z socjologii fenomenologicznej, Kraków.

Skrzypczak B. (2016a), Współczynnik społecznościowy - edukacyjne (re)konstruowanie instytucji społecznościowych w perspektywie pedagogiki społecznej, Toruń.

Skrzypczak B. (2016b), Pomiędzy społecznym a publicznym - nowa przestrzeń edukacji i refleksji, „Pedagogika Społeczna”, nr 3 (61).

Skrzypczak B., Urbańska A. (2016), Kooperatywa spożywcza jako instytucja społecznościowa. Studium przypadku, Warszawa. 
